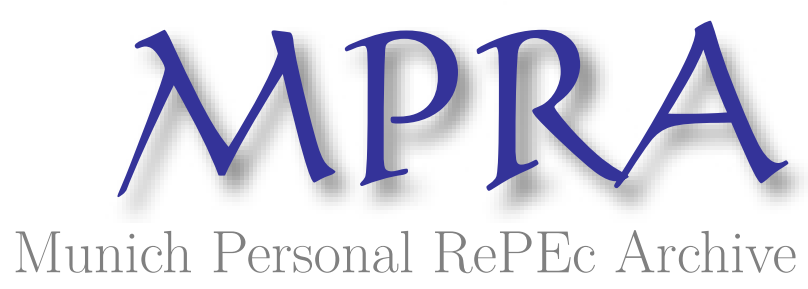

\title{
Institutions, Entrepreneurship and Channels to Sustained Economic Growth
}

Mo, Pak Hung

January 2011

Online at https://mpra.ub.uni-muenchen.de/28911/

MPRA Paper No. 28911, posted 21 Feb 2011 01:29 UTC 


\title{
Institutions, Entrepreneurship and Channels to Sustained Economic Growth
}

\author{
Mo Pak-Hung \\ phmo@hkbu.edu.hk \\ Jan. 2011 \\ Hong Kong Baptist University \\ School of Business \\ Department of Economics
}

\begin{abstract}
In this paper, we build a simple model to integrate the findings and/or hypotheses in the diverse literatures related to economic development and growth. They include the literature on institutions attributed to Douglas North (1990), on entrepreneurs, innovations and technical progress attributed to Schumpeter (1934) and on the driving factors of economic growth in various theoretical and empirical contributions. The effort results in a comprehensive theory that is flexible enough to understand broad strategic lessons from diverse growth experiences across country and time. It is also specific enough to reveal the factors, channels, mechanism and the key to sustained economic growth.
\end{abstract}

Key words: Institution, Entrepreneurship, Tools Variety, Technology, Economic Growth

JEL Classification: O4 


\section{Introduction}

It is the incentive structure imbedded in the institutional/organizational structure of economies that has to be the key to unraveling the puzzle of uneven and erratic growth. < Douglas C. North >

It becomes clear that for analyzing the cause and policies for growth, we need to have a theoretical framework in which growth is endogenous. That is, it depends on the characteristics of institutions and/or environment that govern the costs and benefits of related activities. The model must capture the cause of technical progress, otherwise growth will finally approach zero due to diminishing marginal productivity and limited resources. In this paper, we build a simple model to integrate the findings and/or hypotheses in the diverse literatures related to economic development and growth. They include the literature on institutions attributed to Douglas North (1990), on entrepreneurs, innovations and technical progress attributed to Schumpeter (1934) and on the driving factors of economic growth in various theoretical and empirical contributions. The effort results in a comprehensive theory that is flexible enough to understand broad strategic lessons from diverse growth experiences across country and time. It is also specific enough to reveal the factors, mechanism, channels and the key to sustained economic growth. Long-term growth no longer simply driven by R\&D, human capital or ideas as suggested in the endogenous growth models, it lies deeply in the motivation structure which is specific to the economic, cultural, political and social environments of each economy.

Our model introduces several novelties to understand the growth process. One is the incorporation of the role of entrepreneurs and tools variety on technical progress in sticky competitive markets. The other is modeling the role of institutions in determining people's effort allocation that in turn affect the growth rate of tools variety. The interactions between the two sectors generate virtuous or vicious cycle in progression to the long-term equilibrium growth rate that is largely determined by four variables/parameters specific to the domestic and international environments of an economy. The factors frequently proposed and found to have significant effect on economic growth in various studies can be grouped and understood 
according to their respective effects on the four variables/parameters in the model. The model thus provides a powerful organizing framework for analyzing actual growth phenomena and formulating growth promoting policies.

In the next section, we institute some major insights of Schumpeter (1934) related to tools variety and the role of entrepreneur into the Cobb-Douglas production function (CDOPF). The factors and mechanism determining equilibrium effort allocation, technical progress and therefore long-run growth rate are formulated in Section 3. Section 4 discusses and illustrates graphically the mechanism and effects of globalization on equilibrium growth rate, the possible sources of conditional convergence and the causes of 'leapfrogging' phenomenon. Some factors and the channels through which they might affect technical progress are sketched and tabled in section 5. Section 6 concludes the paper.

\section{The Schumpeterian Cobb-Douglas Production Function (SCDOPF)}

Reviewing the development process across time and country, it is difficult to reject empirically that increase in variety of tools/machines/materials adopted in production is the necessary and sufficient condition for technological advancements. This assertion is popular among historical economists. (among many others, Craft, 2004; Rosenberg, 1976) Schumpeter (1934) emphatically distinguishes innovations from inventions. An invention is an idea, a sketch or model for a new or improved device, product, process or system. Such inventions do not necessarily lead to technical innovations. An innovation in economic sense is accomplished only when the first commercial transaction involving the new product or production method or device is completed. Schumpeter always stresses the crucial role of entrepreneurs in this complex innovative process. As stated in Schumpeter (1934), the carrying out of new combinations can no more be a vocation than the making and execution of strategic decisions. The entrepreneur's essential function must always appear mixed up with other kinds of activity. However, everyone is an entrepreneur only when he actually carries out new combinations. After the insights of Schumpeter (1934) are incorporated into the model, the 
driving factors and the key to sustained economic growth become much more intuitive and straightforward.

There are two inputs, labor and a set of tools that generate capital service. ${ }^{1}$ Behind the production scene is entrepreneur who is responsible for decision-making, risk-taking and most importantly, conducting innovative activities. A representative firm's output level $\left(Y_{j}\right)$ depends on the amount of capital service $\left(K_{j}\right)$ and labor $\left(L_{j}\right)$ employed by the firm $j$, such that:

$$
Y_{j}=K_{j}{ }^{\alpha} L_{j}{ }^{\beta} ; \text { with } \quad \alpha+\beta=1 \text {, and } 0<\alpha<1 \text {. }
$$

In order to introduce the contribution of innovations in production, we follow the approach in the product/input variety literature attributed to Dixit and Stiglitz (1977). Various tools are aggregated by the CES function that gives a positive value to an increase in tools variety in generating capital service, such that:

$$
K_{j}=\left(\sum_{i} X_{i j}^{\theta}\right)^{1 / \theta} ; \quad \text { with } 0<\theta<1 \text { and, } i=1, \ldots h, \ldots v_{j} .^{2}
$$

The parameter $\theta$ governing the elasticity of substitution between the tools is greater than zero and less than one. A higher value of $\theta$ indicates that the tools $\left(X_{i j}\right)$ can be more easily substituted for each other in the production of capital services while lower values of $\theta$ correspond to greater differentiation among the set of tools. The function is similar to Either (1982) and analogous to the ways in which Dixit-Stiglitz (1977) and Krugman (1979), among others, in their measure of utility obtained from a bundle of differentiated consumer goods.

The measurement unit of each tool is normalized so that the unit price of each tool equals to $r$. For all output level, profit-maximizing entrepreneur in firm $j$ chooses an optimal level of each tool, $X_{i j}{ }^{*}$, to maximize the value of capital service $K_{j}=\left(\sum_{i} X_{i j}{ }^{\theta}\right)^{1 / \theta}$ subject to a

\footnotetext{
${ }^{1}$ Man-made tools for enhancing production include simple tools, machines and new materials. Each variety provides differentiated services that are combined to generate specific 'capital service' for production.

2 The function is identical to those in Dixit and Stiglitz (1977). Obviously, the labor service $(L)$ can be treated in an identical manner such that labor service depends on a combination of workers with different skills and human capital. However, the sacrificed technical detail allows us to simply and compactly formalize important ideas about the role entrepreneurs and tools variety in the growth process.
} 
given $C_{j}^{k}$ allocated for capital service with $C_{j}^{k}=\sum_{i} r X_{i j}$. The symmetry implies that all tools variety will be employed with equal quantity, such that for all $i, X_{i j}{ }^{*}=X_{h j}{ }^{*}=X_{j}^{*}\left(r, C_{j}^{k}\right.$, $V_{j}$ ), with $\frac{\partial X_{j}^{*}}{\partial r}<0 ; \frac{\partial X_{j}^{*}}{\partial C_{j}^{k}}>0 ; \frac{\partial X_{j}^{*}}{\partial V_{j}}<0$; where $V_{j}$ is the number of tools variety exogenously given to firm $j$. Therefore, for all output level,

$$
K_{j}^{*}=\left[\sum_{i} X_{i j}^{* \theta}\right]^{1 / \theta}=V_{j}^{1 / \theta} X_{j}^{*}
$$

(E3) indicates that the Dixit-Stiglitz capital service function can be decomposed into the technology component $V_{j}$ and the tools component $X_{j}$. Capital service now has an exact definition. It is an aggregation of the varieties of man-made tools. Moreover, the higher the $V_{j}$, the higher the productivity of $K_{j}{ }^{*}$ and the lower the average cost of capital service $\left(C_{j}^{k} / K_{j}{ }^{*}\right)$ for all $C_{j}^{k}$ and output level. Substituting $K_{j}^{*}$ into the production function, we have:

$$
Y_{j}=V_{j}^{\frac{\alpha}{\theta}} X_{j}^{* \alpha} L_{j}^{\beta}=A_{j} X_{j}^{* \alpha} L_{j}^{\beta} ; \text { where } A_{j} \text { equals } V_{j}^{\frac{\alpha}{\theta}}
$$

Aggregating the production of $n$ identical firms, we have the aggregate production function:

$$
\begin{gathered}
Y=V^{\frac{\alpha}{\theta}} X^{\alpha} L^{\beta}=A X^{\alpha} L^{\beta}, \text { where } A \text { equals } V^{\frac{\alpha}{\theta}} ; \text { and }, \\
\frac{d Y}{Y}=\frac{\alpha}{\theta} \frac{d V}{V}+\alpha \frac{d X}{X}+\beta \frac{d L}{L}=\frac{\alpha}{\theta} d v+\alpha \frac{d X}{X}+\beta \frac{d L}{L}
\end{gathered}
$$

where $X$ and $L$ equals to $n X_{j}^{*}$ and $n L_{j}$ respectively; $d v$ equals $d V / V$ and $(\alpha / \theta) \geq 1 .^{3}$

After incorporating the insights of Schumpeter (1934), the 'A' in the CDOPF is proportional to the number of tools variety employed by entrepreneurs as indicated in (E5).

${ }^{3}$ From (E3), $\frac{\partial K_{j}^{*}}{\partial V_{j}}=V_{j} \frac{1}{\theta}-2 \frac{1}{r / C_{j}{ }^{k}}\left(\frac{1}{\theta}-1\right)>0$. It indicates that the marginal productivity of a new tools variety to capital service is maximized when $\theta$ approaches zero. Since the possibilities of innovation are unlimited, entrepreneurs are motivated to adopt/invent new tools with the lowest $\theta$ to maximize the gain. Market incentives therefore automatically generate the tendency to escape the law of diminishing productivity through innovations. For simplicity, we drop the star in denoting $X$. This has no effect on our analyses since the positive effect of $V_{j}$ on $K_{j}^{*}$ always dominates the negative displacement effect of $V_{j}$ on $X_{j}^{*}$. For more detail discussion, please refer to Mo (2010c). 
Technical progress is equivalent to an increase in the number of tools variety and the key to its increase is the level and effectiveness of entrepreneurial activities in conducting innovations/new combinations during production. ${ }^{4}$ Repeated production of the same tools will finally exhaust the limited resources while the increase in tools variety is potentially unlimited. Sustained economic growth becomes possible when the economy is driven by the increase in tools variety adopted by entrepreneurs.

\section{Institution, Technical Progress, Interaction and Growth Mechanism}

Increasing consensus has been reached that institutions are the most important factor determining the long-term performance of an economy and are responsible for the rise and decline of nations in related literatures. In North $(1990,1994)$, institution is defined as the formal rules (constitutions, statute and common law, regulations, etc.), the informal constraints (norms of behavior, conventions, and internally imposed codes of conduct), and the enforcement characteristics of each. Institutions thus determine the motivation structure of a society and therefore people's effort allocation decisions. As noted in Tullock (1967) and Krueger (1974), among others, in many countries talented people do not become entrepreneurs, but join the government, army, organized religion, and other rent-seeking activities because these sectors offer the highest rewards. Landes (I969) suggests that the differential allocation of talent is one of the reasons why England had the Industrial Revolution in the eighteenth century but France did not. Magee, Brock and Young (1989) discuss rent seeking in great detail and present a model about the allocation of labor between rent seeking and production. Baumol (1990) further suggests that the decline and rise of nations such as ancient Rome, early China, the Middle Ages and Renaissance are driven by the relative payoffs of the society offers to productive activities such as innovation or destructive activities such as rent seeking and

\footnotetext{
${ }^{4}$ In a frictionless competitive market, entrepreneurs will have no incentive to innovate if innovation involves positive costs. However, Shell (1973) demonstrates that when competition is sticky, price-taking competitive markets can induce and support innovations among firms which are finally imitated by all survived firms. For the details, please refer to Mo (2010c).
} 
organized crime. The papers related to Acemoglu (1995, 1998, 2001) further enrich the literature. In this section, we build a simple model that incorporates the role of institutions/motivation structure on people's efforts allocation and its interaction with the technical progress. The outcomes of the interaction determine economic performances across countries and time.

\subsection{Institutions, Motivation Structure and Effort Allocation}

“...the productive contribution of the society's entrepreneurial activities varies much more because of their allocation between productive activities such as innovation and largely unproductive activities such as rent seeking or organized crime. This allocation is heavily influenced by the relative payoffs society offers to such activities." < Baumol, 1990 >

People allocate their effort hours that can contribute to innovations directly. They can also support innovative activities indirectly by providing related services that raise the gains or lower the costs of innovative activities. These productive effort hours $H_{v}$ generate the private return of $B_{v}\left(H_{v}, Z_{v}\right)$. However, the effort hours can also be allocated for rent-seeking or other criminal activities which are denoted by $H_{r}$ with the return of $B_{r}\left(H_{r}, Z_{r}\right)$. Their returns are determined by vectors of environmental and institutional factors denoted by $Z_{v}$ and $Z_{r}$ respectively. The effort allocation decision of people in an economy is represented by the behavior of a typical person. She chooses activities to maximize her utility that depends on the money equivalent benefits $(M)$ generated from a combination of the activities: ${ }^{5}$

$$
\operatorname{Maximize}\left(H_{v}\right): U(M)=U\left[B_{v}\left(H_{v}, Z_{v}\right)+B_{r}\left(H_{e}-H_{v}, Z_{r}\right)\right]
$$

where: $M=B_{v}\left(H_{v}, Z_{v}\right)+B_{r}\left(H_{r}, Z_{r}\right) ; H_{e}$ is the fixed total effort hours and $H_{e}=H_{v}+H_{r}$; $B_{v}^{\prime}\left(H_{v}, Z_{v}\right)=\frac{\partial B_{v}}{\partial H_{v}}=b_{v}\left(H_{v}, Z_{v}\right)>0, B_{v}{ }^{\prime}<0 ; B_{r}^{\prime}\left(H_{r}, Z_{r}\right)=\frac{\partial B_{r}}{\partial H_{r}}=b_{r}\left(H_{r}, Z_{r}\right)>0, B_{r}{ }^{\prime}<0 ;$ and $\frac{\partial B_{v}}{\partial Z_{v}}>0 ; \quad \frac{\partial B_{r}}{\partial Z_{r}}>0$

The first order condition of the optimization problem implies that the marginal benefits of $H_{v}$

\footnotetext{
${ }^{5}$ For simplicity, the efforts of economic agents may choose productive or destructive activities which have positive returns. The rest of the activities are assumed neutral to economic performance and utility.
} 
and $H_{r}$ has to be equal such that $\frac{b_{v}\left(H_{v}{ }^{*}, Z_{v}\right)}{b_{r}\left(H_{r}{ }^{*}, Z_{r}\right)}=1 .^{6}$ This implies $H_{v}{ }^{*}$, the utility-maximizing level of $H_{v}$, is proportional to the relative return between productive and rent-seeking activities, such that:

$$
H_{v}^{*}=f\left(\frac{b_{v}\left(Z_{v}\right)}{b_{r}\left(Z_{r}\right)}\right) \text {; with } H_{v}{ }^{*}+H_{r}{ }^{*}=H_{e}, \text { and } f^{\prime}>0, f^{\prime \prime}<0 .
$$

Institutions embody specific motivation structure that is captured by the levels of $b_{v}$ and $b_{r}$. (E7) thus incorporates the effect of institution/motivation structure in determining people's effort allocation. In competitive markets, the return of productive efforts is proportional to the wage rate $(W)$. The higher the $d v$ in the production sector, the higher the $\mathrm{d} W / W=d w$ that raises the return of productive efforts relative to the return of rent-seeking efforts. ${ }^{7}$ Other things being equal, higher $d v$ raises $b_{v} / b_{r}$ and therefore $H_{v}{ }^{*}$ through the 'wage channel'. The determinants of $H_{v}{ }^{*}$ can therefore be decomposed into two components as follow:

$$
\begin{aligned}
H_{v}^{*} & =f\left[\frac{b_{v}\left(Z_{v}\right)}{b_{r}\left(Z_{r}\right)}\right]=H_{v}^{o}\left[\frac{b_{v}}{b_{r}}\left(Z_{k}\right)\right]+H_{v}^{w}\left\{\frac{b_{v}}{b_{r}}[d w(d v)]\right\} \\
& =H_{v}^{o}\left[\frac{b_{v}}{b_{r}}\left(Z_{k}\right)\right]+\rho d v, \text { with } 0<\rho<1 ;
\end{aligned}
$$

$\rho d v$ is the effort hours induced by $d v$ which captures the effects of technical progress on the people's effort allocation decision. $H_{v}^{o}$ is the 'autonomous' change in the productive effort hours driven by 'non- $d v$ ' factors that are denoted by $Z_{k}$. Other than the 'wage channel' that is driven by the increase in real wage, the $\rho d v$ channel might also include the higher return to investments driven by $d v{ }^{8}$

Numerous contributions suggest and/or identify various factors affecting the $b_{v} / b_{r}$ ratio. Among many other possibilities, $Z_{k}$ includes corruption, the tax and government

\footnotetext{
${ }^{6}$ The diminishing marginal productivity implies that the second order condition is satisfied. The assumption may not be true to a person. To a community as a whole, the assumption is likely to be valid.

${ }^{7}$ In equilibrium, $W$ equals marginal product of labor. (E5) implies that: $\ln W=(\alpha / \theta) \ln V+\beta(\beta-1) \ln L+\alpha \ln X$. The growth rate of $W$ is therefore proportional to $d v$, such that $d w(d v)$ with $d w^{\prime}>0$. Higher $d v$ therefore raises the relative marginal return of productive activities to rent-seeking activities.

${ }^{8}$ Higher $\mathrm{dv}$ raises the level of productive investments when their rates of return increase. For simplicity, we assume that the relationship between $d v$ and $H_{v}^{w}$ is linear. Confining $\rho$ to be less than one will guarantee the stability of the interaction system between $H_{v}$ and $d v$.
} 
expenditure structures, the level and types of transfers or subsidies, the level of socio-political stability and the quality of infrastructures. (E8) thus captures the effects of institutions/motivation structure as well as the rate of technical progress on the allocation of people's efforts which are specific to each country.

\subsection{Technical Progress, Interaction Mechanism and Growth}

"The factors we have listed (innovation, economies of scale, education, capital accumulation, etc.) are not causes of growth; they are growth." < North and Thomas, $1973>$

The next question is what factors determine the growth rate of tools variety in an economy. Economic principles and institutional economists suggest that among some other factors, it is mainly driven by the effectiveness and level of efforts allocated for entrepreneurial/productive activities that directly or supportively contribute to innovations, such that: ${ }^{9}$

$$
d v^{*}\left(H_{v}^{*}, Z_{d}, Z_{f}\right)=d v^{o}\left(Z_{d 1}, Z_{f 1}\right)+\psi\left(Z_{d 2}, Z_{f 2}\right) H_{v}^{*},
$$

In (E9), the driving factors on $d v^{*}$ are decomposed into two components: $d v^{o}$ is the growth rate of tools variety due to the factors unrelated to $H_{v}{ }^{*} \cdot \psi H_{v}{ }^{*}$ is the growth rate of tools variety generated by productive efforts that are endogenously determined by the motivation structure and $d v$ as specified in (E8); $0<\psi<1$ is the parameter indicating the effectiveness of $H_{v}{ }^{*}$ on the $d v . \psi$ and $d v^{0}$ are likely to be affected by vectors of international as well as domestic environments indicated by $\left(Z_{d 1}, Z_{f 1}\right)$ and $\left(Z_{d 2}, Z_{f 2}\right)$ respectively. They include many various factors. For instance, $Z_{f 1}$ includes international technical level and advancements, international communication and transportation costs, international political stability and effectiveness of services provided by international organizations. $Z_{d 2}$ includes the infrastructures favorable to productive and innovative activities such as education/training supports and opportunities for

\footnotetext{
9 Besides the well known historical and institutional literatures, Murphy, Shleifer and Vishny (1991) find supportive empirical evidences that countries with higher rent-seeking activities have negative feedback effects on the growth potential of the economy. For simplicity, we assume all relationships are linearly related.
} 
domestic and international exchanges. $d v^{*}$ is thus driven by international as well as domestic factors.

Now we have the simultaneous equations (E8) and (E9) relating $H_{v}$ and $d v$. Solving for the equations, we have the general equilibrium levels of:

$$
\begin{aligned}
& H_{v}^{* *}=[1 /(1-\psi \rho)] H_{v}^{o}+[\rho /(1-\psi \rho)] d v^{o} ; \text { and }, \\
& d v^{* *}=[1 /(1-\psi \rho)] d v^{o}+[\psi /(1-\psi \rho)] H_{v}^{o} ;
\end{aligned}
$$

The solutions indicate that the initial changes in $d v^{o}$ and/or $H_{v}^{o}$ generate cumulative changes on both variables. In the historical and institutional economics literatures as well as the endogenous growth models, it is commonly suggested that modern economic development with sustained technical progress, $d v^{* *}>0$, occurs only when the institutions protecting intellectual property rights were sufficiently well developed such that entrepreneurs could capture part of the social returns generated from their innovations. (for instance, North, 1990; Romer, 1990) This hypothesis emphasizes the importance of the incentives to professional innovators as captured in (E8). However, our model demonstrates that the key for development is indicated by (E10b). Sustained growth happens when $d v^{0}>0$ and/or the economy has positive $\psi$ and $H_{v}^{o}$. (E10b) also demonstrates that stagnation, $d v^{* *}=0$, is rare and difficult to most economies. It requires that $d v^{o}$ and $H_{v}^{o}($ or $\psi)$ equal to zero. Innovations driven by learning from doing in production among entrepreneurs and the creative instinct of humankind suggest that $\psi$ and $H_{v}^{o}$ have tendency to be greater than zero. International technical spillovers also suggest that $d v^{0}>0$. Therefore, sustained growth is likely to be natural if people have economic freedom and operate under proper infrastructures. Long-term stagnation and poverty usually happen only when governments/organized powers intentionally destroy knowledge and technology periodically and create institutions targeted at suppressing innovative activities in order to protect their own vested interests. In fact, the intentional elimination of growth possibilities by organized powers through suppressing the key growth parameter and variables in $(\mathrm{E} 10 \mathrm{~b}), d v^{o}, H_{v}^{o}$ and $\psi$, to zero through policies like prohibiting international exchanges, 
repressing the spread of technical know-how and instituting deleterious motivation structure is well-documented in related literature. (for instance, Mo, 1995 and 2004)

In order to visualize the virtuous/vicious interactions between $d v$ and $H_{v}$, we introduce the time element into the simultaneous equation system. The stability requirement of the system, its dynamic process and the associated phenomena in the progression towards higher or lower growth over time can be observed accordingly. Assume a higher $d v$ induces higher contemporary productive efforts through raising the marginal return of the efforts; while the growth rate of tools variety in this period depends on the productive efforts of the last period, such that:

$$
H_{v}{ }^{*}=H_{v}^{o}+\rho d v^{*}{ }_{t} ; \text { and }, \quad d v^{*}{ }_{t}=d v^{o}+\psi H_{v}{ }^{*}(t-1) \text {. }
$$

Through repeated substitutions, we can observe the progression of the two variables evolving towards the steady state as demonstrated in Table $1:^{10}$

\section{Table 1: The Cumulative Effect and Mechanism of $d v^{*}$ and $H_{v}{ }^{*}$}

\begin{tabular}{ccc} 
Time & $\Delta \boldsymbol{H} \boldsymbol{v}^{*}$ & $\Delta \boldsymbol{d} \boldsymbol{v}^{*}$ \\
\hline $\mathbf{1}$ & 1 & $\psi$ \\
$\mathbf{2}$ & $\psi \rho$ & $\psi^{2} \rho$ \\
$\mathbf{3}$ & $\psi^{2} \rho^{2}$ & $\psi^{3} \rho^{2}$ \\
$\mathbf{4}$ & $\psi^{3} \rho^{3}$ & $:$ \\
$:$ & $:$ & $:$ \\
$\infty$ & 0 & 0 \\
\hline
\end{tabular}

\section{Insert Table 1 about here}

Table1 indicates that the initial increase/decrease in $H_{v}{ }^{*}$ and/or $d v^{*}$ generates cumulative changes in both variables over time. The rise of a nation can be understood as an improvement in motivation structure that generates cumulative increase in technical progress and productive efforts under the virtuous cycle between $d v^{*}$ and $H_{v}{ }^{*}$. The process normally also generates

\footnotetext{
10 The stability of the system requires $\psi \rho<1$ that is satisfied when the parameters are assumed to be less than one and greater than zero. Solving the equations, we can have the difference equations of the respective variables.
} 
induced improvements in infrastructures and institutions when production surplus and standard of living improves. Similarly, a nation declines when it experiences institutional degradation and therefore simultaneous declines in technical progress and productive efforts generated by the vicious cycle between $d v^{*}$ and $H_{v}{ }^{*}$.

\section{Effects of Globalization, Sources of Conditional Convergence and Leapfrogging}

Graphical analyses are more effective to visualize the interaction mechanism and the factors determining the equilibrium technical progress or equivalently, the rate of sustained economic growth across countries and time. In Figure 1, we use the model to analyze the effects of globalization. The effects of institutional degradation in an economy are illustrated in Figure 2. Figure 3 provides a mechanism for conditional convergence due to the 'hungry and lean effect' and Figure 4 demonstrates another reason for conditional convergence. The sources of conditional convergence can explain the leapfrogging phenomenon when the Olson's (1982) hypothesis of 'cumulative distortions' is incorporated.

Globalization raises the extent of market as well as renders international exchanges in tools variety and organization methods available to entrepreneurs. (for instance, Mo, 2010a) The expansion of tools variety through international exchanges raises $d v^{o}$ as well as $\psi$, the productivity of productive efforts. This results in a virtuous cycle driving the economy from the low level equilibrium $\left(d v_{1}{ }^{* *}, H_{v 1}{ }^{* *}\right)$ towards a higher level equilibrium $\left(d v_{2}{ }^{* *}\right.$, $H_{v 2}{ }^{* * *}$ ) as illustrated in Figure 1. The process can help us to understand the successful stories of some East Asian countries that sequentially liberalize their economies to capture the benefits of globalization generated from the expansion of tools variety. (Mo, 2010b)

\section{Insert Figure $1 \& 2$ about here}

Figure 2 illustrates the effects generated by institutional degradation in an economy. The degradation is equivalent to the decline in relative benefits of productive activities to 
rent-seeking activities as well as a decrease in the marginal return to productive, innovative and investment activities. The reduction in $\frac{b_{v}}{b_{r}}$ results in a lower $H_{v}^{o}\left(\frac{b_{v}}{b_{r}}\right)$ while the decrease in marginal return to productive activities results in lower $\rho$. They generate a vicious cycle driving the economy from a high level equilibrium $\left(d v_{1}{ }^{* *}, H_{v 1}{ }^{* *}\right)$ to a low level equilibrium $\left(d v_{2}{ }^{* *}, H_{v 2}{ }^{* *}\right)$.

Figure 1: Globalization: Both $d v^{o}$ and $\psi$ increase

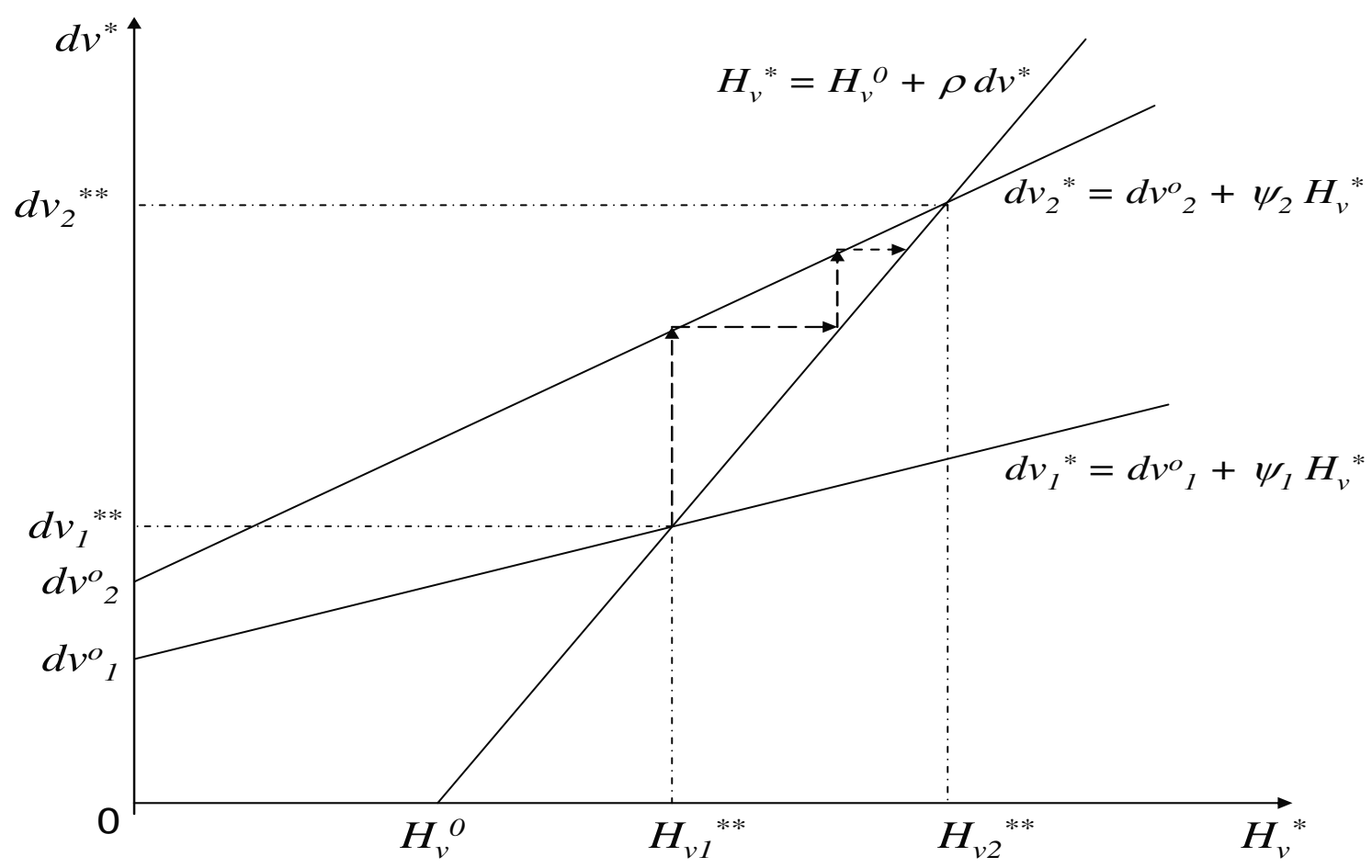


Figure 2: Degradation of Institutions: $H_{v}{ }^{o}$ and $\rho$ Decreases

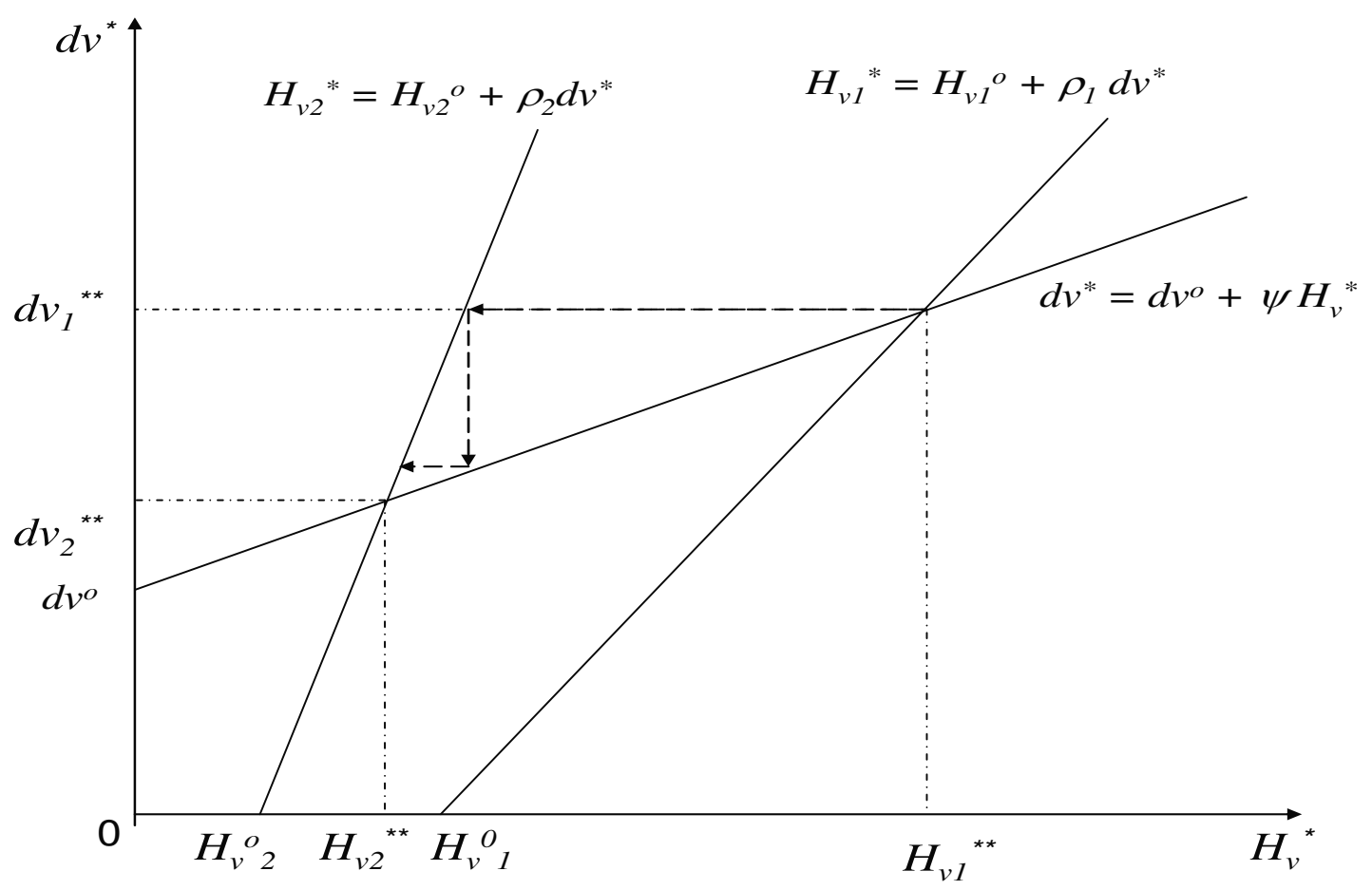

Figure 3: 'Hungry and Lean' versus 'Full and Fat'

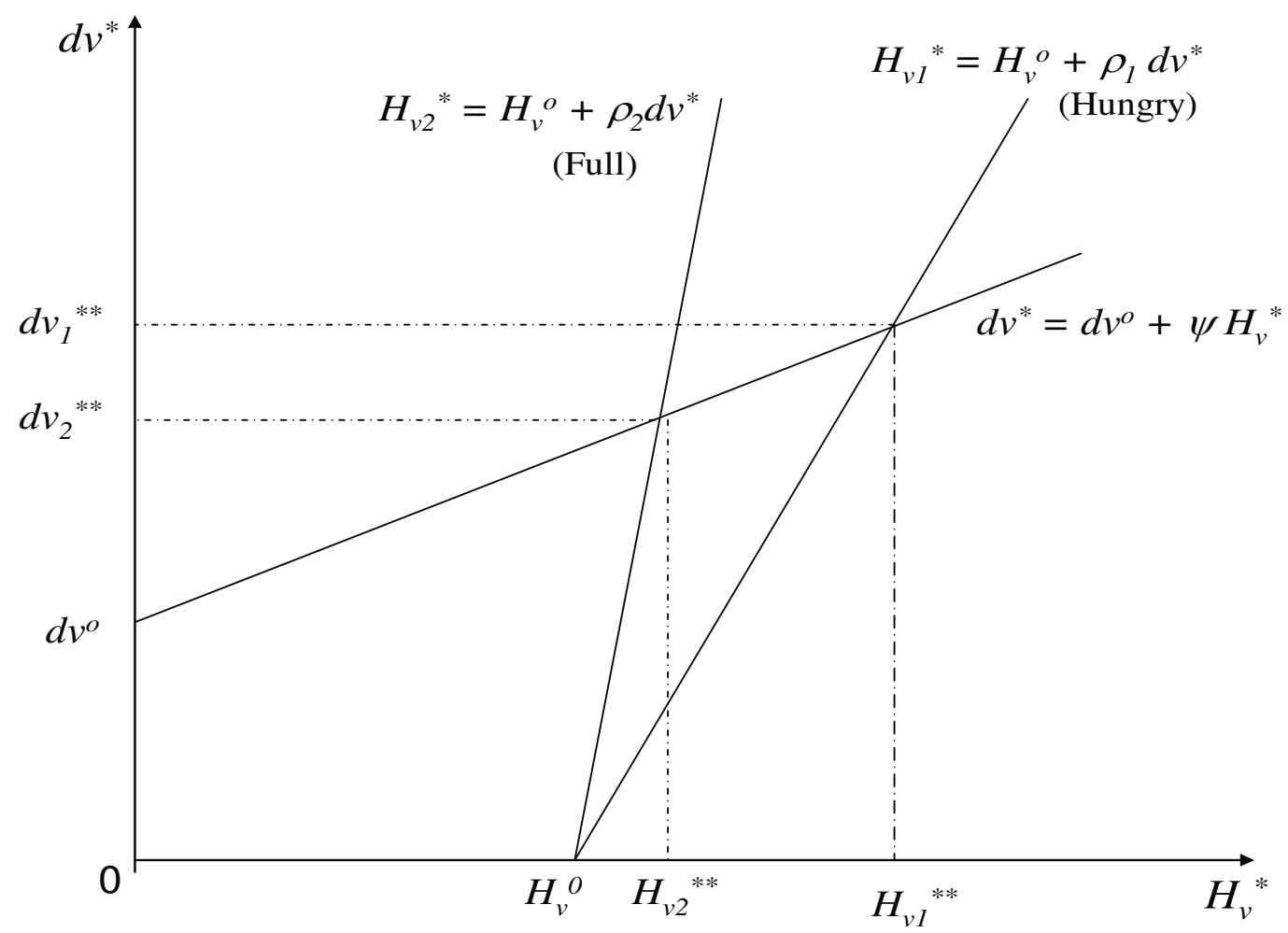

Note: Hungry and lean people tend to be more 'opportunistic': with higher $\rho$. 
Figure 4: Catch-up by Imitations

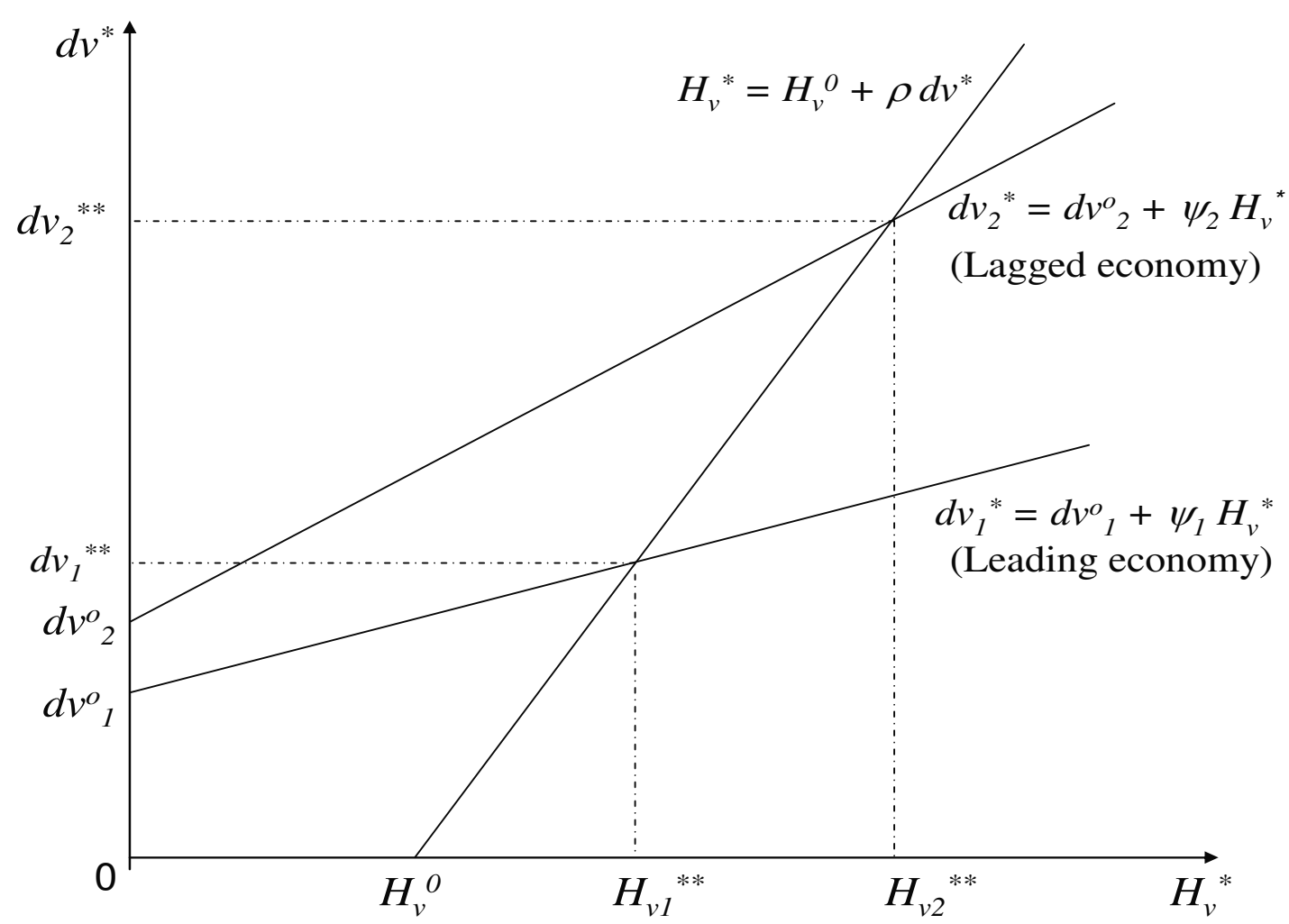

Note: Lagged economies have higher $d v^{o}$ and $\psi$ as imitation is easier than invention.

Conditional convergence has strong empirical regularity in the data on countries and regions as suggested in Barro (1998), among many other findings. Figure 3 and 4 provide two possible channels for conditional convergence to occur. Figure 3 illustrates that driven by hunger, basic needs and desires, poor people are eager to grab opportunities and benefits to improve their wellbeing. When other things being equal, these economies tend to be more 'opportunistic' with higher $\rho$ and therefore have higher equilibrium $H_{v}$ and $d v$.

\section{Insert Figure $3 \& 4$ about here}

Figure 4 provides another possibility for the conditional convergence. Lower income countries normally have low level of technology or equivalently, with less tools variety. Since imitation and/or importation of advance tools are much less costly than acquiring them by $\mathrm{R} \& \mathrm{D}$, lagged economies tend to have higher $d v^{0}$ and $\psi$ than advanced economies when other things being equal. This can result in higher $d v^{* *}$ in lagged economies than the leading economies when they have comparable quality of public governance. The insight on 
'cumulative distortions' suggests that old developed countries tend to have more distortions in the bureaucratic decision process. (Olson, 1982) Therefore, lower quality of public governance and motivation structure in old developed economies resulted in lower $H_{v}^{o}$ and $\rho$ than those newly-developed economies. ${ }^{11}$ After developing economies catch-up with the leading economies through the two 'conditional convergence channels', the less cumulative distortions in newly-developed economies, or equivalently, the better motivation structure, generates higher $\left(d v^{* *}, H_{v}^{* *}\right)$ as shown in Figure 2. The mechanisms result in the 'leapfrogging' phenomenon commonly observed in the rise and decline of nations across time. ${ }^{12}$

\section{The Key, Channels and Factors for Sustained Economic Growth}

To summarize, the key for any technical progress is the increase in tools variety that are driven by the level and effectiveness of entrepreneurial activities while the channels of every factor affecting technical progress can be separated into two categories and four groups:

\section{Motivation Category:}

Group M1: The factors $Z_{k}$ that determines $H_{v}^{o}$ through $H_{v}^{o}\left[\frac{b_{v}}{b_{r}}\left(Z_{k}\right)\right]$. For instance, the government expenditure and tax structures, level of corruption and distribution of opportunities.

Group M2: The factors determine the productive efforts induced by $d v$

\footnotetext{
11 The empirical study in Mo (2009) finds that minimum wage has cumulative negative effects on productivity, investment and growth. Lindbeck and Nyberg (2006) and Michau (2009), among others, also provide some evidences and the possible sources of 'cumulative distortions' as suggested in Olson (1982). The empirical observations and the causes of leapfrogging suggested in this paper are therefore mutually supportive.

12 As noted in Brezis, Krugman, and Tsiddon (1993), endogenous growth theory fails to explain the historical evidences that the role of international leadership among countries shifts. They suggest a mechanism that explains this pattern of 'leapfrogging' as a response to occasional major changes in technology. When the new technology proves more productive than the old, leapfrogging of leadership occurs. With the insight of Olson (1982) and the conditional convergence literature, our model provides the alternative mechanism in explaining this common observation.
} 
through $H_{v}^{w}\left\{\frac{b_{v}}{b_{r}}[d w(d v)]\right\}$. They include the size of market, stock of human capital, tax and expenditure structure, resources mobility and government supports to entrepreneurial activities. In general, they include all factors determining the motivation and effectiveness of the economic agents in reacting to the opportunities and challenges generated by $d v$.

\section{Technical Category:}

Group T1: The factors denoted by $\left(Z_{f 1}, Z_{d 1}\right)$ that drive the autonomous growth rate of tools variety through $d v^{o}\left(Z_{f 1}, Z_{d 1}\right)$. They include spillovers generated by technical progress of foreign countries, distance to the sea and trade policies that determine the intensity of international exchanges.

Group T2: The factors denoted by $\left(Z_{d 2}, Z_{f 2}\right)$ that determine $\psi\left(Z_{d 2}, Z_{f 2}\right)$, the marginal productivity of $H_{v}$ on the growth rate of tools variety. They include the infrastructures and government supports available to innovative activities as well as the international and domestic exchange opportunities.

Table 2 lists some factors that are commonly considered to have effects on economic growth in related literatures. Employing our analytical framework, we suggest the possible channels and directions through which they effect on the rate of technical progress and therefore economic growth. The suggestions are only tentative as the actual effects of a policy can be highly specific to initial conditions of each country. (for instance, Mo, 2010b) Moreover, we do not discuss the details on the mechanism although readers can always refer to some related works and find analogies in the graphical analyses as presented in the last section. However, the nice thing of our framework is that the effects of all factors on long-run economic growth can always be judged by their final impacts on the growth of tools and its variety adopted by entrepreneurs in their production process.

\section{Insert Table 2 about here}


Table 2: Factors and Channels affecting Technical Progress and Growth

\begin{tabular}{|c|c|c|c|c|}
\hline \multirow[t]{2}{*}{ Growth Factors } & \multicolumn{4}{|c|}{ Channels Affecting Technical Progress and Growth } \\
\hline & $H_{v}^{o}=\left[\frac{b_{v}}{b_{r}}\left(Z_{k}\right)\right]$ & $\rho=\frac{\partial\left(H_{v}^{*}\right)}{\partial(d v)}$ & $d v^{o}\left(Z_{d 1}, Z_{f l}\right)$ & $\frac{\partial(d v)}{\partial H_{v}}=\psi$ \\
\hline Economic freedom and factors mobility & + & + & + & + \\
\hline International exchanges \& competition ${ }^{1}$ & + & + & + & + \\
\hline Rewards contingent on productive activities & + & + & + & + \\
\hline Exploitative government ${ }^{2}$ & - & - & - & - \\
\hline Corruption $^{3}$ & - & - & - & - \\
\hline Financial system efficiency & + & + & + & + \\
\hline Education supports ${ }^{6,7}$ & + & + & + & + \\
\hline Lack of access to sea & - & - & - & - \\
\hline Logographic writing system ${ }^{4}$ & + & + & + & + \\
\hline Ethnic and religious conflicts & - & - & - & - \\
\hline Private property rights protection & + & + & + & 0 \\
\hline Stock of human capital ${ }^{5}$ & 0 & + & + & + \\
\hline Ex-ante opportunity inequality ${ }^{6}$ & - & - & 0 & - \\
\hline Taxing land rent and other unearned incomes ${ }^{6}$ & + & + & + & 0 \\
\hline Government Consumption/tax rate ${ }^{7}$ & - & - & - & 0 \\
\hline Aggregate demand sufficiency ${ }^{7}$ & + & + & + & 0 \\
\hline Urbanization and industrial cluster & 0 & + & + & + \\
\hline Intellectual property right protection & + & + & + & 0 \\
\hline Per capita GDP / technology level & 0 & 0 & - & - \\
\hline Intensity of political activities ${ }^{8}$ & - & - & 0 & 0 \\
\hline Tropical climate & - & - & 0 & 0 \\
\hline Increase in foreign $d v$ & 0 & 0 & + & + \\
\hline
\end{tabular}

Notes:

Please refer to the following papers for some related discussions, among many others: ${ }^{1}$ Mo(2010a, 2010b); ${ }^{2}$ Mo(1995, 2004);

${ }^{3}$ Mo(2001a); ; ${ }^{4}$ Mo (2007a, 2008a); ${ }^{5} \operatorname{Mo}(2002) ;{ }^{6}(2000,2003,2009 a) ;{ }^{7}$ Mo (2007c); ${ }^{8} \operatorname{Mo}(2001 b, 2007 b, 2009 b)$.

Now, we have a model that captures the key, channels and mechanism of technical progress and long-term growth. The rise of European economies experienced in recent centuries can be understood as a virtuous cycle between technical progress, productive activities, production surplus and the institutional factors driving technical progress. Unlike the situation in imperial China, the intense inter-country competitions in the European continent forced the dictators to adopt institutions favorable and supportive to entrepreneurial activities, technical progress and 
economic growth. (for instance, Jones, 1981) Under the environment, the invention and adoption of mechanical energy in production lowered transportation cost that raised the market size as well as the intensity of international interactions and competitions. Also, increase in production surplus allowed increasing scale of infrastructures, urban clusters and investments, raising the stock of human capital and releasing the resources for survival activities to innovative ventures. They generated a virtuous circle of explosion in tools variety that kicked start the industrial revolution. The globalization process along with intense competitions and increased market size further the dynamism towards global explosion in tools and its variety.

\section{Conclusion: Economics is a 'BullsMo' Science}

The cause of sustained economic growth and development is one of the most important issues in economics. How can we explain the immense differences in income and technical progress across the world? What can policy do about it? In this paper, we construct a simple model to link up some important insights of Schumpeter (1934) with the contributions from the literatures relating to institutions, endogenous growth theories and empirical findings on growth determinants. The model provides clear answers and mechanism for the above important questions. Tools variety increase is the only key for technical progress which is observable, endogenously determined and interacts with people's effort allocation decisions. While the key and channels to sustained economic growth are narrowly defined, the model is general enough to understand various driving factors and mechanism that explain sustained growth, growth explosion, decline and stagnation across economies and time. International competition becomes the competition on the quality of public governance. It determines the quality of institutions/motivation structure, public policies and infrastructures supportive to entrepreneurial activities and therefore the growth rate of tools variety. ${ }^{13}$ Empowered with the framework, policymakers now have the precise target and instructions that are short, clear and

\footnotetext{
${ }^{13}$ Mo (2007c) provides some supportive evidences on this conclusion. The structure of public expenditures that largely capture the quality of public governance and determine the motivation structure facing economic agents in an economy can explain more than 80 percent of the long-term growth rate across countries.
} 
easy to implement. It condenses the findings and suggestions by many books and articles into a one single target: instituting appropriate motivation structure, policies and supports that are favorable to entrepreneurs for expanding the tools and its variety in their production process.

Standing on the shoulders of the giants, we transform a 'dismal science' that describes a world of scarcity, stagnation, decline and diminishing returns into a discipline that shows unlimited possibilities. Our model suggests that zero growth occurs only under very specific conditions. When self-interest maximizing agents interact under appropriate environments, entrepreneurs are automatically motivated to escape the law of diminishing productivity by innovations. The potential virtuous cycle between technical progress, productive activities and favorable infrastructures can generate a 'Bulls Momentum' that opens up the possibility of progressive and sustained economic growth. This suggests that economics is no longer a dismal science but a 'BullsMo' science that can potentially bring us to an earthly paradise.

This study supports the insight attributed to North (1990) where he argues that the central issue of economic history and of economic development is to account for the evolution of political and economic institutions that create an economic environment determining the increase/decline in productivity. Only with the knowledge, we are able to devise constraints and infrastructures for political, economic and social interactions such that the entrepreneurial vitality and therefore the growth of tools variety can forever be sustained. Will the development of humankind finally hit the carrying capacity of the earth? May be yes. Will we finally reach the carrying capacity of the universe? I do not know. But with the unlimited possibilities of tools variety and unlimited creativity among humankind societies, the chance is very slim. The BullsMo framework in this paper suggests that we have no destined ending. Our ending depends on whether we can instill desirable motivation structure into our societies. It is embodied in our public policies, organizations, economic and social infrastructures that are predominantly affected by the quality of public governance. They are ultimately dependent on our knowledge, vision, wisdom, choices and determination. 


\section{REFERENCES}

Abramovitz, Moses (1986) "Catching Up, Forging Ahead and Falling Behind," Journal of Economic History 46, 385-406.

Acemoglu, Daron (1995) "Reward Structures and the Allocation of Talent," European Economic Review 39, 17-33.

and T. Verdier (1998) "Property Rights, Corruption and the Allocation of Talent: A General Equilibrium Approach," Economic Journal 108, 1381-403.

, Johnson and Robinson (2001) "The Colonial Origins of Comparative Development: An Empirical Investigation,” The American Economic Review 91(5), 1369-1401.

Adelman, Irma (1961) Theories of Economic Growth and Development. Stanford University Press, Stanford, California.

Aghion, P., and P. Howitt (1992) "A Model of Growth through Creative Destruction," Econometrica 60, 323-351.

Alesina, Ozler, Roubini and Swagel (1996) "Political Stability and Economic Growth," Journal of Economic Growth 1, 189-211.

Barro, Robert (1991) "Economic Growth in a Cross-Section of Countries," Quarterly Journal of Economics 106, 407-43. (1997) Determinants of Economic Growth: A Cross-Country Empirical Study. MIT Press.

and X., Sala-i-Martin (1992) "Convergence," Journal of Political Economy 100(2), 223-51.

Baumol, William (1990) "Entrepreneurship: Productive, Unproductive, and Destructive," The Journal of Political Economy 98 (5), 893-921.

(2000) "What Marshall Didn't Know: On the Twentieth Century's Contributions to Economics," Quarterly Journal of Economics 115(1), 1-44.

Benhabib, J. and M. Spiegel (1994) "The Role of Human Capital in Economic Development: Evidence from Aggregate Cross-Country Data," Journal of Monetary Economics 34, 
Bernard, A. and C. Jones (1996) "Technology and Convergence," The Economic Journal 106, 1037-1044.

Bessant, J. and J. Tidd (2007) Innovation and Entrepreneurship. John Wiley \& Sons.

Brezis, Krugman and Tsiddon (1993) "Leapfrogging in International Competition: A Theory of Cycles in National Technological Leadership," American Economic Review 83 (5), 1211 1219.

Cobb C. and P. Douglas (1928) "A Theory of Production," American Economic Review 18, $139-65$

Crafts, Nicholas (2004) "Productivity Growth in the Industrial Revolution: A New Growth Accounting Perspective," The Journal of Economic History 64 (2), 521-535.

Dasgupta, P. and J. Stiglitz (1988) "Learning-by-Doing, Market Structure and Industrial and Trade Policies," Oxford Economic Papers 40, 246-268.

Dixit, A. and J. Stiglitz (1977) "Monopolistic Competition and Optimum Product Diversity," The American Economic Review 67(3), 297-308.

Easterly, W. and R. Levine (1997) "Africa' s Growth Tragedy: Policies and Ethnic Divisions," Quarterly Journal of Economics 112(4), 1203-50. (2001) "What have we learned from a decade of empirical research on growth? It's Not Factor Accumulation: Stylized Facts and Growth Models," World Bank Economic Review 15 (2), 177-219.

Ethier, Wilfred (1982) 'National and International Returns to Scale in the Modern Theory of International Trade,' American Economic Review 72, 389-405.

George, Henry (1879) Progress and Poverty: An Inquiry into the Cause of Industrial Depressions and of Increase of Want with Increase of Wealth. New York: Robert Schalkenbach Foundation.

Gerschenkron, Alexander (1968) "Chapter 6: The Modernization of Entrepreneurship" in Continuity in History and other Essays. The Belknap Press of Harvard University Press, Cambridge, Massachusettts. 
Grossman, G. and E. Helpman (1991) Innovation and Growth in the Global Economy. MA: MIT Press.

Hall, R. and C. Jones (1999) "Why Do Some Countries Produce So Much More Output Per Worker Than Others?" Quarterly Journal of Economics1999 114(1), 83-116.

Jones, Eric (1981) The European Miracle: Environments, Economies and Geopolitics in the History of Europe and Asia. Cambridge: Cambridge University Press.

Jones, Charles (1997) "On the Evolution of the World Income Distribution," Journal of Economic Perspectives 11, 19-36.

Knack, S. and P. Keefer (1995) "Institutions and Economic Performance: Cross-Country Tests Using Alternative Institutional Measures,” Economics and Politics 7, 207-227.

Krueger, Anne (1974) "The Political Economy of the Rent-Seeking Society," American Economic Review LXIV, 291-303.

Krugman, Paul (1979) "A Model of Innovation, Technology Transfer, and the World Distribution of Income," Journal of Political Economy 87, 253-266.

La Porta, Lopez-de-Silanes, Shleifer and Vishny (1999) "The Quality of Government," Journal of Law, Economics, and Organization, 15(1), 222-79. (1998) "Law and Finance," Journal of Political Economy 106(6), 1113-55.

Landes, David (1969) The Unbound Prometheus, New York: Cambridge University Press. (1998) The wealth and poverty of nations: Why some are so rich and some so poor. New York: W.W. Norton \& Co..

(1949) "French entrepreneurship and industrial growth in the nineteenth century, Journal of Economic History 9, 45-61.

Lindbeck, A. and S. Nyberg (2006) "Raising Children to Work Hard: Altruism, Work Norms, and Social Insurance," The Quarterly Journal of Economics 121(4), 1473-1503.

Lucas, Robert (1988) "On the Mechanics of Economic Development," Journal of Monetary Economics 22, 3-42. 
(1990) “Why Doesn't Capital Flow from Rich to Poor Countries?” American Economic Review 80, 92-96.

Magee, Brock and Young (1989) Black Hole Tariffs and the Endogenous Policy Theory, Cambridge: Cambridge University Press.

Mankiw, Romer and Weil (1992) "A Contribution to the Empirics of Economic Growth," Quarterly Journal of Economics 107(2), 407-38.

McDougall, William (1921) National Welfare and National Decay, Methuen \& Co., London.

Michau, Jean-Baptiste (2009) "Unemployment Insurance and Cultural Transmission: Theory and Application to European Unemployment," CEP Discussion Paper No. 936. at: http://cep.1se.ac.uk/pubs/download/dp0936.pdf. <Access date: 28 July 09>

Mo, P. H. (1995) "Effective Competition and Economic Development of Imperial China," Kyklos 48, 87-103. (2000) “Income Inequality and Economic Growth,” Kyklos 53, 293-316.

(2001a) "Corruption and Economic Growth", Journal of Comparative Economics 29, 66-79.

(2001b) "Level of Political Rights and Economic Growth: Transmission Mechanism and Effects," School of Business, Hong Kong Baptist University.

(2002) "Human Capital and Economic Growth - Alternative Specifications," School of Business, Hong Kong Baptist University.

(2003) “Land Distribution Inequality and Economic Growth," Pacific Economic Review 8( 2), 171-181.

(2004) "Lessons from the History of Imperial China," in Political Competition, Innovation and Growth in the History of Asian Civilizations, Peter Bernholz and Roland Vaubel (eds.), Edward Elgar, U.K..

(2007a), "The Nature of Chinese Collective Values: Formation and Evolution," International Journal of Chinese Culture and Management 1(1), 108-125.

(2007b), "Rational Democracy: A Political System for Universal Interest," School of Business, Hong Kong Baptist University. 
(2007c), "Government Expenditures and Economic Growth: the Supply-side and the Demand-side," Fiscal Studies 28(4), 497-522.

(2008a) "Language Divides and Global Inequalities: Problems and Solutions," in The China Information Technology Handbook, Ordóñez de Pablos, Patricia; Lytras, Miltiadis D. (Eds.), Springer.

(2008b) "The Supply-side and Demand-side Effects of Government Size and investment," International Journal of Economic Perspectives 2(3), 150-168.

(2009a) "Income Distribution Polarization and Economic Growth," Indian Economic Review 44( 1), 107-123.

(2009b) "The Effects of Wage-Labor Regulations: Much More Damaging than Expected," School of Business, Hong Kong Baptist University.

(2010a) “Trade Intensity, Net Export and Economic Growth," Review of Development Economics 14, 563-576.

(2010b) “Trade Liberalization Sequence for Sustained Economic Growth," Paper presented at the Sixth Annual Conference APEA 2010, Hong Kong Baptist University, Hong Kong, July 8-9, 2010.

(2010c) "Entrepreneurs, Sticky Competition and the Schumpeterian Cobb-Douglas Production Function," School of Business, Hong Kong Baptist University.

(with W. Suen) (1994) "Simple Analytics of Productive Consumption," Journal of Political Economy, 102(2):372-383.

and S.K. Li (1998) "Contract Responsibility Systems and Productive Efficiency - A Case Study on State-Owned Enterprises in China," Bulletin of Economic Research 50(4): 323-341.

Murphy, Shleifer, Vishny (1991) “The Allocation of Talent: Implications for Growth," The Quarterly Journal of Economics 106 (2), 503-530.

(1993) "Why is rent-seeking so costly to growth?" American Economic Review, Papers and Proceedings 83, 409-414.

Norris, Pippa (2001) Digital Divide, Civic Engagement, Information Poverty, and the Internet Worldwide. Cambridge University Press. 
North, Douglass (1981) Structure and Change in Economic History, New York: W.W. Norton \& Co..

(1990) Institutions, Institutional Change and Economic Performance. Cambridge University Press.

(1995) "Five Propositions about Institutional Change," in Explaining Social Institutions, Knight and Sened, eds.. Ann Arbor: University of Michigan Press.

(1994) "Economic Performance Through Time," The American Economic Review 84(3), 359-368.

, and R. Thomas (1973) The Rise of the Western World: A New Economic History. Cambridge: Cambridge University Press.

, and B.Weingast (1989) "The Evolution of Institutions Governing Public Choice in $17^{\text {th }}$ century England," Journal of Economic History 5, 172-200.

, Summerhill, and Weingast (2000) "Order, Disorder, and Economic Change: Latin America Versus North America,” In Bruce Bueno de Mesquita and Hilton L. Root, eds., Governing for Prosperity. New Haven: Yale University Press.

Olson, Mancur (1971) [1965] The Logic of Collective Action : Public Goods and the Theory of Groups. Harvard University Press.

(1982) The Rise and Decline of Nations. Yale University Press.

Pack, Howard (1994) "Endogenous Growth Theory: Intellectual Appeal and Empirical Shortcomings," Journal of Economic Perspectives 8, 55-72.

Rodrik, Dani (2004) "Industrial Policy for the Twenty-First Century,” Discussion Paper Series No. 4767. London: Centre for Economic Policy Research.

(1999) "Where Did All the Growth Go?" Journal of Economic Growth 4(4), 385-412.

, Subramanian and Trebbi (2004) "Institution Rule: The Primacy of Institutions over Geography and Integration in Economic Development," Journal of Economic Growth 9, 131-165.

Romer, Paul (1990) "Endogenous Technological Change," Journal of Political Economy, 98(5), S71-S102. 
(2007) "Economic Growth," The Concise Encyclopedia of Economics, David R. Henderson, ed.. Liberty Fund.

Rose-Ackerman, Susan (1975) "The economics of corruption," Journal of Public Economics 4, 187-203.

Rosenberg, Nathan (1976) Perspectives on technology. New York: Cambridge University Press.

(1982) Inside the Black Box: Technology and Economics. Cambridge: Cambridge University Press. and L. E. Bridzell (1985), How the West Grew Rich? New York: Basic Books.

Schumpeter, Joseph (1934) The Theory of Economic Development, trans. Redvers Opie. Cambridge: Harvard University Press. (orig. German lang. ed., 1911).

Shell, Karl (1973) "Inventive Activity, Industrial Organisation and Economic Growth." In: Models of Economic Growth, edited by James A. Mirrlees and Nicholas H. Stern. New York: Wiley.

Shleifer, A. and R. Vishny (1998) The Grabbing Hand. Harvard University Press.

Squire, Lyn (1993) "Fighting Poverty", The American Economic Review, 83(2), 337-82.

Stigler, George (1946) “The Economics of Minimum Wage Legislation", The American Economic Review 36(3), 358-65.

(1971) "The Theory of Economic Regulation," The Bell Journal of Management and Science 3, 3-18.

Solow, Robert (1956) "A Contribution to the Theory of Economic Growth," Quarterly Journal of Economics 70, 65-94.

(1957) "Technical Change and the Aggregate Production Function," Review of Economics and Statistics 39, 312-20.

Tullock, Gordon (1967) "The Welfare Cost of Tariffs, Monopoly and Theft," Western Economic Journal 5, 224-32. 
Svensson, Jakob (1998) "Investment, Property Rights and Political Instability: Theory and Evidence," European Economic Review 42(7), 1317-41.

Weingast, Barry (1995) "The Economic Role of Political Institutions: Market-Preserving Federalism and Economic Development," Journal of Law, Economics, and Organization $11,1-31$. 